IRA-International Journal of Management \& Social Sciences

ISSN 2455-2267; Vol.06, Issue 03 (2017)

Pg. no. 345-353

Institute of Research Advances

https://research-advances.org/index.php/RAJMSS

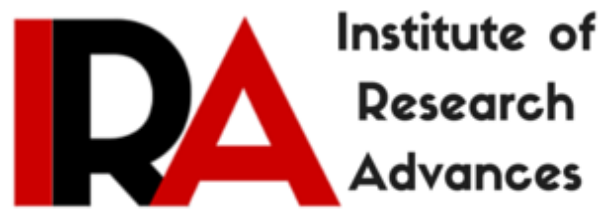

\title{
Influence of Demographic Factors on Visitor Perceived Value and Visitor Satisfaction in Bangalore Amusement Parks
}

\author{
${ }^{1}$ Avinash BN, ${ }^{2}$ Dr. Vidyavathi K \\ ${ }^{1}$ Research Scholar, Sahyadri College of Engineering \& Management, Adyar, Mangalore, \\ India. \\ ${ }^{2}$ Professor, Sahyadri College of Engineering \& Management, Adyar, Mangalore, India.
}

Type of Review: Peer Reviewed.

DOI: http://dx.doi.org/10.21013/jmss.v6.n3.p2

\section{How to cite this paper:}

BN, A., \& K, V. (2017). Influence of Demographic Factors on Visitor Perceived Value and Visitor Satisfaction in Bangalore Amusement Parks. IRA-International Journal of Management \& Social Sciences (ISSN 2455-2267), 6(3), 345-353. doi:http://dx.doi.org/10.21013/jmss.v6.n3.p2

(C) Institute of Research Advances (cc) EY-NO

This work is licensed under a Creative Commons Attribution-Non Commercial 4.0 International License subject to proper citation to the publication source of the work.

Disclaimer: The scholarly papers as reviewed and published by the Institute of Research Advances (IRA) are the views and opinions of their respective authors and are not the views or opinions of the IRA. The IRA disclaims of any harm or loss caused due to the published content to any party. 


\begin{abstract}
The service industry is the most dynamic and ever growing industry in terms of revenue and competition. In order to compete and survive successfully in today's dynamic environment, all the service providing organisations focus on enhancing their diverse customer base having different demographical patterns that arise after the fulfillment of needs and wants of customers to maximise their profits. The amusement park industry is not an exception to this situation in present market dynamism. With the increase in the number of parks and decrease in footfalls, the amusement parks are in the process to enhance their park image by concentrating on the demographic factors of the visitors. Therefore, researchers are intensely emphasising on the influence of demographic factors on the visitor perceived value and visitor satisfaction. The current research study endeavors to find out the relationship among demographic factors on the perceived value and visitor satisfaction. The sample data is collected from random customers of different amusement parks in Bangalore. The collected data then analyzed using SPSS. The results revealed that there is no significance relation between demographic factors and visitor perceived value and visitor satisfaction.
\end{abstract}

Keywords: Amusement Parks, Demographic factors, Perceived value, Visitor satisfaction, Park image

\title{
INTRODUCTION
}

Amusement park industry in India is more than two decades old and is still in a nascent stage. The opening up of the AppuGhar, the first amusement park in 1984 led to the beginning of the industry in India. Later the expansion of the industry took place with the opening of Essel World in Mumbai, NiccoPark in Chennai, Ramoji Film city in Hyderabad etc, Though the amusement parks are a nascent industry in India, there exist a huge scope for growth. But the need of the hour is to know what they are doing and for whom. There has to be a focus on safety and hygiene with creativity in each and every product on offer. In this industry, a lot of people go through the system and highlights the need for complex machinery. So, there is a need to make sure that the right people with the right attitude come into the sector (Chittilapilly, 2016).

Demographic factors are personal characteristics are used to collect and evaluate data on people in a given population (Avinash B N, 2017). Typical factors include age, gender, marital status, race, education, income and occupation. Demographic factors reveal customer profile that may have some impact on perceived value and customer satisfaction. Researchers have attempted to explain the relation between customer satisfaction and loyalty all over the world in many of the studies but a very few have tried to understand the impact of demographic factors on satisfaction (Khraim, Al-Jabaly, \& Khraim, 2014). Therefore, current research endeavors to examine the impact of customer demographics on perceived value and customer satisfaction in Amusement Parks industry.

\section{LITERATURE REVIEW}

The concept perceived value is considered as universally accepted and it is the consumer's overall assessment of the utility of a product or service based on customer perceptions of what is received and what is given(Varki. S and Colgate. M, 2001). Perceived value is the comprehensive assessment of the utility of perceived benefits and perceived sacrifices, or as the difference between perceived benefits and paid costs; it is also the ratio of perceived benefits in relation to the perceived sacrifices(Khraim, Al-Jabaly, \& Khraim, 2014).Advertised selling price, advertised reference price and internal reference price are the determinants of the perceived value among different price structures(Jacoby., 1977). The customer encompasses all the costs of sacrifices like purchasing, acquisition and installation of the product or services while perceived benefits are the combinations of physical attributes of the available service in a given relationship of the product use(Khraim, AlJabaly, \& Khraim, 2014). 
In the study on examining the effects of price bundling on perceived value, the results proved that providing an all-inclusive price package, even if actual monetary outlay is higher, will significantly increase perceptions of value for first-time consumers (Wildt, 1994). It is argued that in the context of consumer behaviour, the perceived value is the primary aspect a customer pursues from an exchange (Naylor, 2001). The amount of value he gets for the money paid is the deciding factor for whether or not to use a service provider or exchange once more (Lai, 2009). Despite the significance of perceived value's effect on customer's assessment of services, little study has been conducted on the link between this variable and its impact on consumer's behavioral intention (Park, 2006).

One of the most important theoretical as well as practical issues for most marketers and customer researchers during the last five decades is the customer satisfaction (Caruana, 2004). Customer satisfaction according to the customers is the degree to which the products or services received are worth more than the price they paid (Jamal, 2004). Business usually measures the customer satisfaction from the behavior of customer after they get interact with organization about their products or services, such as decreasing of customer complain, repurchasing(Tracey, 1996), positive word of mouth, and increase in the volume of purchases.

Every study on consumer behaviour, proposes customer satisfaction extensively as a construct(McDougall, 2000)(Fornell, 1992). Customer satisfaction is perceived as a result of purchase and consumption experience valued for a product or service over a period of time (Anderson, 1994)(Oliver R. L., 1999). Consumer's response to fulfillment which is a judgment on a product or service or any of its feature's ability to provide an enjoyable level of fulfillment is the customer satisfaction(Oliver R. , 1997).In other words, customer satisfaction stands for emotional state of a customer with reference to pleasure or disappointment due to comparison between his expectations and perceptions about a product's performance(Kotler, 2006).

While differentiating satisfied and dissatisfied customers, Tarus and Rabach (2013) postulated that a dis-satisfied customer is one whose expectations exceeded the actual outcome of service interaction whereas a satisfied or delighted customer is a case of interaction matching or surpassing expectations. Customer's consumption experience over a period of time with regard to a particular product or service is customer satisfaction (Fornell, 1992).

\section{OBJECTIVES OF THE STUDY}

The objective of the study is to establish the relation between demographic factors, perceived value and satisfaction in the amusement park industry special reference to the visitors of amusement parks in Bangalore. The study tries to examine the relation between the following:

A. Visitor's demographic factors and Visitor Perceived Value

B. Visitors demographic factors and Visitor Satisfaction

\section{CONCEPTUAL MODEL}

The conceptual model of this research study is derived from the literature review of various research works carried out by many researchers on perceived value and visitor satisfaction in various industries like banking, retail etc., This study tries to find the link between different demographic aspects of the visitor of a Bangalore-based amusement parks with Visitor Perceived Value and Visitor Satisfaction.

Based on the review of previous researches in the field of consumer behaviour on the demographic factors this study employs the following model. The demographic variables such as visitor Gender, Age, Income, Education and Occupation are considered as independent variables whereas Visitor Perceived Value and Visitor Satisfaction as dependent variables. 


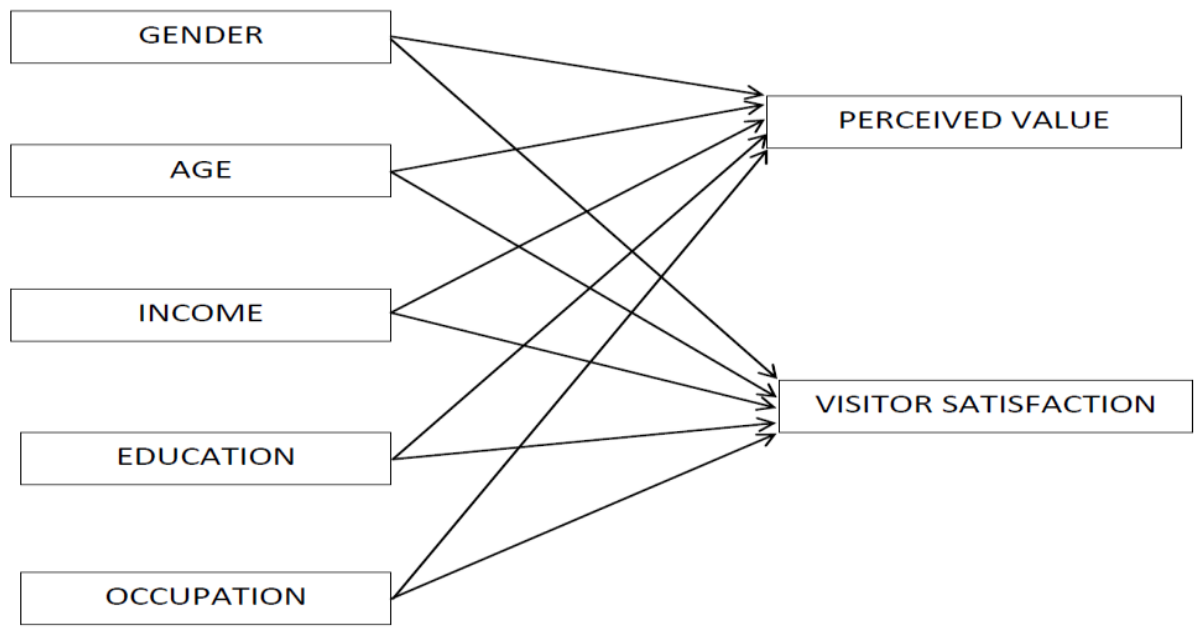

Figure 1: Conceptual model

\section{HYPOTHESIS}

The following hypotheses are formulated to establish and test the relation and its significance of different demographic factors with perceived value and visitor satisfaction of the amusement park industry in general and Bangalore-based amusement parks in particular.

\section{Influence of demographic factors on Visitor Perceived Value.}

H 1.1: Visitor Age has a significant influence on Visitor Perceived Value.

H 1.2: Visitor Gender has a significant influence on Visitor Perceived Value.

H 1.3: Visitor Income has a significant influence on Visitor Perceived Value.

H 1.4: Visitor Education has a significant influence on Visitor Perceived Value.

H 1.5: Visitor Occupation has a significant influence on Visitor Perceived Value.

\section{Influence of demographic factors on Visitor Satisfaction.}

H 2.1: Visitor Age has a significant influence on Visitor Satisfaction.

H 2.2: Visitor Gender has a significant influence on Visitor Satisfaction.

H 2.3: Visitor Income has a significant influence on Visitor Satisfaction.

H 2.4: Visitor Education has a significant influence on Visitor Satisfaction.

H 2.5: Visitor Occupation has a significant influence on Visitor Satisfaction.

\section{RESEARCH METHODOLOGY}

This study employs a quantitative method of research in which primary data is collected from a random sample of 150 visitors of Bangalore amusement Parks. The data collection method is based on survey research questionnaire adopted from previous studies due to the benefit of collecting significant information from the respondents. The data was collected in June 2016 to August 2016 
period from 8 important amusement parks in and around Bangalore which has a significant number of footfalls and have a considerable size of operation.

While selecting the amusement park, qualification criteria were fixed with respect to size, footfalls, revenue, the area of operation, games, rides and other recreational facilities in their campus. Likert's five point scale is employed in the questionnaire to record the responses with 1-stongly Disagree, 2- Disagree, 3- Neutral, 4- Agree and 5- Strongly Agree. The questionnaire consisted of three portions Visitor Perceived Behaviour, Visitor Satisfaction and demographic patterns.

\section{ANALYSIS AND INTERPRETATION}

The data was processed and analyzed using SPSS. Descriptive and Inferential statistics were used to interpret the data. The findings are recorded and interpreted as follows. Reliability check was done using Croanbach's Alpha and it was found significant of 0.815. The demographic details and their frequencies were found as the following.

\begin{tabular}{|c|c|c|c|c|}
\hline SL NO & DEM. FACTOR & VARIABLE & FREQUENCY & PERCENT \\
\hline \multirow{2}{*}{1} & \multirow{2}{*}{ GENDER } & MALE & 89 & 59.30 \\
\hline & & FEMALE & 61 & 40.70 \\
\hline \multirow{4}{*}{2} & \multirow{4}{*}{ AGE } & $10-20$ & 3 & 2.00 \\
\hline & & $20-30$ & 55 & 36.70 \\
\hline & & $30-40$ & 15 & 10.00 \\
\hline & & $>40$ & 77 & 51.30 \\
\hline \multirow{4}{*}{3} & \multirow{4}{*}{ INCOME } & $<1$ Lakh & 30 & 20.00 \\
\hline & & 1-3 Lakhs & 33 & 22.00 \\
\hline & & 3-5 Lakhs & 43 & 28.70 \\
\hline & & $>5$ Lakhs & 44 & 29.30 \\
\hline \multirow{4}{*}{4} & \multirow{4}{*}{ EDUCATION } & $<$ SSLC & 3 & 2.00 \\
\hline & & PUC & 26 & 17.30 \\
\hline & & $\mathrm{UG}$ & 41 & 27.30 \\
\hline & & $>\mathrm{PG}$ & 80 & 53.30 \\
\hline \multirow{4}{*}{5} & \multirow{4}{*}{ OCCUPATION } & Student & 15 & 10.00 \\
\hline & & Employed & 80 & 53.30 \\
\hline & & Business & 41 & 27.30 \\
\hline & & Home maker & 14 & 9.30 \\
\hline
\end{tabular}

From Table 1, it is evident that, approx. 59\% of the respondents were Males and Females constitutes only $41 \%$ of the sample population. It shows a whopping $51 \%$ of the respondents are from the age group of Above 40 years and $37 \%$ of the respondents fall in the age group of 20-30 years. In case of income level, almost 59\% of the respondents are earning More than 3 lakhs per annum.

Out of the contacted respondents, $80 \%$ have at least a graduate degree and 53\% have Post graduate degree and above. It also shows the different occupations of the respondents, Employed constitutes nearly $53 \%$ of the total respondents, $27 \%$ pursue business as their profession and $10 \%$ each constitutes Students and Homemakers. 


\begin{tabular}{|c|c|c|c|}
\hline \multicolumn{5}{|c|}{ TABLE 2: DEMOGRAPHIC FACTORS * VISITOR PERCEIVED VALUE } \\
\hline DEMOGRAPHIC FACTORS & CHI-SQUARE VALUE & DF & P-VALUE \\
\hline VISITOR AGE & & & \\
\hline VISITOR GENDER & 30.318 & 3 & 0.300 \\
\hline VISITOR INCOME & 3.098 & 1 & 0.761 \\
\hline VISITOR EDUCATION & & & \\
\hline VISITOR OCCUPATION & 17.504 & 3 & 0.918 \\
\hline
\end{tabular}

The above Table 2 shows the association between various Demographic Factors and Visitor Perceived Value in terms of Chi-square value. From the above table, the following results can be inferred.

The Visitor Age v/s Visitor Perceived Value has a Chi-Square value of 30.318 and significance value of 0.300 which is greater than the critical value of 0.05 . The hypothesis $\mathrm{H} 1.1$ : Visitor Age has a significant influence on Visitor Perceived Value is rejected. That means there is no relation between Visitor Age and Visitor Perceived Value.

The Visitor Gender v/s Visitor Perceived Value has a Chi-Square value of 3.098 and significance value of 0.761 which is greater than the critical value of 0.05 . The hypothesis $H 1.2$ : Visitor Gender has a significant influence on Visitor Perceived Value is rejected. Implies there is no relation between Visitor Gender and Visitor Perceived Value.

The Visitor Income v/s Visitor Perceived Value has a Chi-Square value of 17.504 and

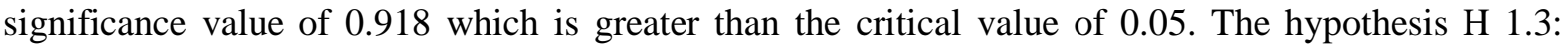
Visitor Income has a significant influence on Visitor Perceived Value is rejected. Hence there is no relation between Visitor Income and Visitor Perceived Value.

The Visitor Education v/s Visitor Perceived Value has a Chi-Square value of 22.249 and significance value of 0.725 which is greater than the critical value of 0.05 . The hypothesis $\mathrm{H} 1.4$ : Visitor Education has a significant influence on Visitor Perceived Value is rejected. So, there is no relation between Visitor Education and Visitor Perceived Value.

The Visitor Occupation v/s Visitor Perceived Value has a Chi-Square value of 35.899 and significance value of 0.118 which is greater than the critical value of 0.05 . The hypothesis $\mathrm{H} 1.5$ : Visitor Occupation has a significant influence on Visitor Perceived Value is rejected. It concludes that there is no relation between Visitor Occupation and Visitor Perceived Value. 


\begin{tabular}{|c|c|c|c|}
\hline \multicolumn{4}{|c|}{} \\
\hline TABLE 3: DEMOGRAPHIC FACTORS * VISITOR SATISFACTION \\
\hline DEMOGRAPHIC FACTORS & CHI-SQUARE VALUE & DF & P-VALUE \\
\hline VISITOR AGE & 29.707 & 3 & 0.761 \\
\hline VISITOR GENDER & 10.004 & 1 & 0.616 \\
\hline VISITOR INCOME & 32.791 & 3 & 0.622 \\
\hline VISITOR EDUCATION & 37.219 & 3 & 0.413 \\
\hline VISITOR OCCUPATION & 45.423 & 3 & 0.135 \\
\hline
\end{tabular}

The above Table 3 shows the association between various demographic factors and Visitor Satisfaction in terms of Chi-square value. From the above table, the following results can be inferred.

The Visitor Age v/s Visitor Satisfaction has a Chi-Square value of 29.707 and significance value of 0.761 which is greater than the critical value of 0.05 . The hypothesis $\mathrm{H}$ 2.1: Visitor Age has a significant influence on Visitor Satisfaction is rejected. That means there is no relation between Visitor Age and Visitor Satisfaction.

The Visitor Gender v/s Visitor Satisfaction has a Chi-Square value of 10.004 and significance value of 0.616 which is greater than the critical value of 0.05 . The hypothesis $\mathrm{H}$ 2.2: Visitor Gender has a significant influence on Visitor Satisfaction is rejected. Implies there is no relation between Visitor Gender and Visitor Satisfaction.

The Visitor Income v/s Visitor Satisfaction has a Chi-Square value of 32.791 and significance value of 0.622 which is greater than the critical value of 0.05 . The hypothesis $\mathrm{H}$ 2.3: Visitor Income has a significant influence on Visitor Satisfaction is rejected. Hence there is no relation between Visitor Income and Visitor Satisfaction.

The Visitor Education v/s Visitor Satisfaction has a Chi-Square value of 37.219 and

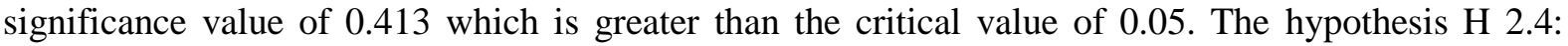
Visitor Education has a significant influence on Visitor Satisfaction is rejected. So, there is no relation between Visitor Education and Visitor Satisfaction.

The Visitor Occupation v/s Visitor Satisfaction has a Chi-Square value of 45.243 and significance value of 0.135 which is greater than the critical value of 0.05 . The hypothesis $\mathrm{H} 2.5$ : Visitor Occupation has a significant influence on Visitor Satisfaction is rejected. It concludes that there is no relation between Visitor Occupation and Visitor Satisfaction.

Overall in this study, as revealed by chi-square test the Demographic Characters of the amusement park visitors has no relation with Visitor Perceived Value and Visitor Satisfaction.

\section{CONCLUSION}

The major thrust of this study is to find the influence of demographic factors on visitor perceived value and visitor satisfaction of the Bangalore amusement parks visitor. The satisfied customer finally becomes a loyal customer to the product or service as a frequent visitor. Satisfaction can only be achieved by fulfilling the customer needs and expectations by creating and surpassing the visitor perceived value. The conversion of a satisfied customer to loyal customer is a challenging task and needs to be tackled carefully by enhancing the perceived value of the products or services. 
Though the demographic factors influence the consumer behaviour, but in this study with respect to the visitors of amusement parks of Bangalore different demographic factors are not so significant or crucial. The study concludes that the various demographic factors have no influence on the visitor perceived value or visitor satisfaction. Therefore, in today's competitive and highly potential amusement park industry, perceived value and customer satisfaction must be assured by the organization by focusing on value creation, needs fulfillment, meeting customer expectations along with targeting the demographic characters of the visitors to gain strategic and competitive edge in industry, retaining and building loyal customer base for the organization.

\section{LIMITATIONS AND RECOMMENDATIONS}

As this study was conducted with the limited random sample size of 150 visitors of the Bangalore amusement Parksthere is a wide and enormous space for improvement of this study by employing a different mode of data collection and different ways of analysis as well. The data collected is only from the Bangalore-based amusement parks hence this geographical restriction for the study itself is a limitation of the study. The results of any study depends on the sample size, hence this can be further improved by collecting more samples from all over the geographical regions with structured method of data collection.

\section{References}

Anderson, E. W. (1994). Customer satisfaction, market share and profitability:findings from Sweden. Journal of Marketing, 58(2), 112-122.

Avinash B N, K. Vidyavathi. (2017). Influence of demographic factors on Visitor loyalty and Visitor switching behaviour in Bangalore Amusement Parks. Unpublished.

Caruana, A. (2004). The impact of switching costs on customer loyalty: A study among corporate customers of mobile telephony. Journal of Targeting, Measurement and Analysis for Marketing., Vol. 12, No. 3: 256-268.

Chittilapilly, W. H. (2016, June 8). (ETNOW, Interviewer)

Fornell, C. (1992). A national customer satisfaction barometer. Journal of Marketing, 56 (1),.

Jacoby., J. O. (1977). Consumer response to price: an attitudinal, information-processing perspective. American Marketing Association, Chicago, 73-86.

Jamal, A. (2004). Retail banking and customer behavior: a study of self concept, satisfaction and technology usage. International Review of Retailing, Distribution and Consumer Research., Vol. 14 No. 3, pp. 357-79.

Khraim, H. S., Al-Jabaly, S. M., \& Khraim, A. S. (2014). Universal Journal of Management 2(5), 186-196.

Kotler, P. \&. (2006). Marketing Management. 12th ed. Prentice Hall.

Lai, F. G. (2009). How quality, value, image, and satisfaction create loyalty at Chinese telecom. Journal of Business Research, Vol.62: 980-986.

McDougall, G. \&. (2000). Customer satisfaction with services: putting perceived value into the equation. Journal of Services Marketing, 14 (5), 392-.

Naylor, G. a. (2001). The effect of price bundling on consumer perceptions of value. Journal of Services Marketing, Vol. 15 Nos 4/5, pp. 270-81. 
Oliver, R. (1997). Satisfaction: A Behavioral Perspective on the consumer. New York NY: McGrawHill.

Oliver, R. L. (1999). Whence customer loyalty? Journal of Marketing, 63, 33-44.

Park, J. R. (2006). Modeling the Impact of Airline Service Quality and Marketing Variables on Passengers' Future Behavioral Intentions. Transportation Planning and Technology., Vol.29, No.5.

Tracey, M. A. (1996). Logistics/purchasing effectiveness, manufacturing flexibility and firm performance: Instrument development and causal model analysis. Toledo,: The University of Toledo,.

Varki. S and Colgate. M. (2001). The role of price perceptions in an integrated model of behavioral intentions. Journal of Service Research, Vol.3, No. 3: 232-240.

Wildt, C. T. (1994). Price, product information, and purchase intention: an empirical study. Journal of the Academy of Marketing Science, Vol. 22 No. 1, pp. 16-27. 